\title{
PENGARUH FLYPAPER EFFECT TERHADAP BELANJA DAERAH DI PEMERINTAHAN SE-EKS KARESIDENAN PATI
}

\author{
Afif Fatimatuz, Zahroh ', Naila Rizki Salisa ${ }^{2}$ \\ Program Studi Akuntansi, Fakultas Ekonomi dan Bisnis, Universitas Muria Kudus \\ IAfif.Zahro@yahoo.com \\ 2 Naila.Rizki@umk.ac.id
}

\begin{abstract}
ABSTRAK
Penelitian ini bertujuan untuk menguji apakah Pengaruh Flypaper Effect Terhadap Belanja Daerah. Populasi dalam penelitian ini mencakup 6 Kabupaten/Kota Se-Eks Karesidenan Pati. Adapun periode penelitian yang digunakan dalam penelitian ini adalah tahun 2012-2016. Pengambilan sampel menggunakan metode sensus, yaitu semua anggota populasi dijadikan sampel. Teknik analisis data yang digunakan yaitu uji asumsi klasik dan analisis regresi berganda. Berdasarkan hasil analisis bahwa Dana Alokasi Umum (DAU), Pendapatan Asli Daerah (PAD) berpengaruh signifikan terhadap Belanja Daerah. Hasil analisis membuktikan bahwa Pemerintahan/Kota Se-Eks Karesiden Pati mengalami Flypaper Effect dengan rata-rata kontribusi Dana Alokasi Umum terhadap Belanja Daerah sebesar $54,5 \%$ lebih tinggi di bandingkan dengan kontribusi Pendapatan Asli Daerah terhadap Belanja Daerah sebesar $12,1 \%$.
\end{abstract}

Kata Kunci : Flypaper Effect, Dana Alokasi Umum, Pendapatan Asli Daerah, Belanja Daerah.

\section{ABSTRACT}

This Study aims to examine whether the flypaper effect on regional spending. The population in this study includes 6 regencies or cities in Pati residency. While the study period used in this study period used in this study is the year 2012-2016. Sampling using the census method, ie all members of the of the population are sampled. The techniques used are classical assumption test and multiple regression analysis. Based on the result of the analysis that the general allocation fund, the origional regional income has a significant effect on regional expenditure. The results of the analysis prove that the government/ city of the former residency of starch experienced a flypaper effect with an average contribution of general allocation funds to regional expenditure of 54,5\% hight compared to the contribution of local revenue to regional expenditure of $12,1 \%$.

Keywords : Flypaper Effect, General Allocation Fund, Local Revenue, Regional Expenditure. 


\section{PENDAHULUAN}

Otonomi daerah merupakan fenomena politis yang menjadikan penyelenggaraan pemerintahan yang sentralistik birokratis ke desentralisasi partisipatoris. Penerapan otonomi daerah di Indonesia, yang hingga saat ini merupakan wujud dari diberlakunya UU No.32 Tahun 2004 tentang Pemerintah Daerah dan UU No.33 Tahun 2004 tentang Perimbangan Keuangan antara Pemerintah Pusat dan Pemerintah Daerah. Kedua Undang-undang ini sebagai pengganti dari undang-undang No.22 Tahun 1999 dan No.25 Tahun 1999 tentang Pemerintahan Daerah dan Perimbangan Keuangan antara Pemerintahan Pusat dan Daerah (Rahmawati dan Suryono, 2015).

Kebijakan daerah tidak lagi bersifat "given" dan "uniform" (selalu menerima dan seragam) dari pemerintah pusat, namun justru pemerintahan daerah yang harus mengambil inisiatif dalam merumuskan kebijakan daerah yang sesuai dengan aspirasi, potensi, dan sosiokultural masyarakat setempat. Disini yang dimaksud dalam kebijakan yang tidak lagi bersifat "given" dan "uniform" yaitu kebijakan dalam pemerintah daerah tidak lagi sama dengan kebijakan yang telah ditentukan dengan pemerintah pusat. Melainkan pemerintah daerah memiliki kewenangan dalam mengembangkan program-program pemberdayaan ekonomi di daerahnya.

Pemberian otonomi daerah bertujuan untuk mewujudkan kemandirian daerah sehingga daerah bebas untuk mengatur dirinya tanpa ada campur tangan pemerintah pusat. Keberhasilan pengembangan otonomi daerah bisa dilihat dari derajat otonomi fiskal daerah yaitu perbandingan antara Pendapatan Asli Daerah (PAD) dengan total penerimaan Anggaran Penerimaan dan Belanja Daerah (APBD) nya yang semakin meningkat, diharapkan dimasa yang akan datang ketergantungan daerah terhadap transfer dana pusat hendaknya diminimalisasi guna menumbuhkan kemandirian pemerintah daerah dalam pelayanan publik dan pembangunan (Rahmawati dan Suryono, 2015).

Pembangunan daerah merupakan pembangunan yang semuanya dipersiapkan dan dilaksanakan oleh daerah dengan memanfaatkan sumber daya yang ada di daerah tersebut. Pesatnya pembangunan daerah membutuhkan alokasi dana pembangunan yang besar sehingga menyebabkan belanja pemerintahan daerah juga semakin meningkat. Besarnya belanja daerah ditentukan oleh besarnya pendapatan daerah yang bersangkutan. Instansi pemerintah daerah 
yang menerima anggaran belanja tentunya harus mampu menunjang pertumbuhan belanja daerah sehingga dapat meningkatkan kesejahteraan masyarakat dari setiap kota/kabupaten yang ada di Indonesia (Kainde, 2013).

Permasalahan yang berkaitan dengan belanja daerah terletak pada anggaran daerah dari pemerintah pusat yang sepenuhnya belum digunakan dalam pembiayai pembangunan infrastruktur daerah, sebagian besar masih digunakan untuk membiayai belanja pegawai sehingga pembangunan infrastruktur tidak bisa berjalan dengan lancar sesuai rencana. Keterlambatan dalam anggaran belanja daerah juga disebabkan karena adanya faktor penyimpangan dana APBD dengan adanya penyimpangan dana anggaran pendapatan dan belanja negara (APBN) yang mempengaruhi pembangunan daerah dan bantuan dari pemerintah tak semuanya utuh.

Tujuan dalam penelitian ini untuk menganalisis apakah Pemerintahan/ Kota Se-Eks Karesidenan Pati masih mengandalkan dana perimbangan yaitu dana alokasi umum yang di berikan oleh pemerintah pusat kepada pemerintah daerah. dengan adanya pelimpahan wewenang diharapkan pemerintah daerah dapat mengali sumber-sumber pendapatan asli daerahnya sehingga mampu membiayai pengeluaran belanja daerah dan tidak terjadi flypaper effect dan otonomi daerah dapat terwujud.

\section{TINJAUAN PUSTAKA}

Teori keagenan (agency theory) merupakan teori yang menjelaskan hubungan prinsipal dan agen, ini salah satunya berakar pada teori ekonomi, teori keputusan, sosiologi, dan teori organisasi. Teori prinsipal-agen menganalisis susunan kontraktual di antara dua atau lebih individu, kelompok, atau organisasi. Salah satu pihak (prinsipal) membuat suatu kontrak, baik secara implisit maupun eksplisit dengan pihak lain (agen) dengan harapan bahwa agen akan bertindak atau melakukan pekerjaan seperti yang dinginkan oleh (prinsipal) dalam hal ini terjadi pendelegasian wewenang. Hubungan prinsipal-agen terjadi apabila tindakan yang dilakukan seseorang memiliki dampak pada orang lain (Halim dan Abdullah, 2006).

Dalam kaitan agency theory dalam penelitian ini dapat dilihat melalui hubungan antara Pemerintahan Pusat dengan Pemerintahan Daerah dalam rangka pemberian otonomi daerah kepada daerah didasarkan atas asas desentralisasi dalam wujud otonomi yang luas, nyata, dan 
bertanggung jawab. Peran Pemerintahan Pusat (prinsipal) di era otonomi daerah ini adalah lebih banyak hal-hal yang berkaitan dengan penetapan kebijakan nasional dan pengendalian serta memberikan hak kepada pemerintahan daerah (agen) untuk mendapatkan sumber penerimaan keuangan sesuai dengan urusan Pemerintah yang diserahkan, dalam hal ini pemerintah menetapkan prinsip-prinsip uang berdasarkan fungsi. Oleh karena itu, sebagai konsekuensi dari otonomi daerah yang mana pemerintahan pusat melimpahkan wewenang kepada pemerintahan daerah untuk mengatur secara mandiri segala aktivitas pemerintahanya di daerah. Pemerintahan pusat menurunkan dana perimbangan sebagai salah satu sumber penerimaan daerah untuk membantu daerah dalam mendanai kewenanganya (Jensen dan Meckling, 1976).

\section{Belanja Daerah}

Belanja daerah merupakan semua pengeluaran dari rekening kas umum daerah yang mengurangi ekuitas dana, yang merupakan kewajiban daerah dalam satu tahun anggaran dan tidak memperoleh pembayaranya kembali oleh daerah (Kawedar dkk, 2008:184).

Belanja daerah dibagi menjadi dua bagian untuk memudahkan penilaian kewajaran biaya suatu program atau kegiatan, kelompok belanja terdiri dari belanja langsung dan belanja tidak langsung. Belanja langsung merupakan belanja yang dianggarkan terkait secara langsung dengan pelaksanaan program dan kegiatan, sebaliknya dengan belanja tidak langsung merupakan belanja yang dianggarkan tidak terkait secara langsung dengan pelaksanaan program dan kegiatan (Rahmawati dan Suryono, 2015).

\section{Flypaper Effect}

Flypaper Effect merupakan suatu kondisi keuangan pemerintah daerah yang membelanjakan lebih banyak dan lebih boros dengan menggunakan dana transfer, atau dana alokasi umum dibandingkan dengan menggunakan dana sendiri atau pendapatan asli daerah (Mentayani dkk, 2012).

\section{Dana Alokasi Umum}

Dana alokasi umum adalah dana yang bersumber dari Anggaran Pendapatan dan Belanja Negara $(\mathrm{APBN})$ yang dialokasikan dengan tujuan pemerataan kemampuan keuangan antar daerah untuk mendanai kebutuhan daerah (Rahmawati dan Suryono, 2015). 


\section{Pendapatan Asli Daerah}

Pendapatan asli daerah adalah semua pendapatan yang berasal dari sumber ekonomi asli daerah, dimana diklasifikasikan menjadi empat jenis pendapatan yaitu : pajak daerah, retribusi daerah, hasil pengelolaan kekayaan daerah yang dipisahkan dan lain-lain pendapatan asli daerah (Bastian dan Soepriyanto, 2003:83).

\section{Kerangka Penelitian}

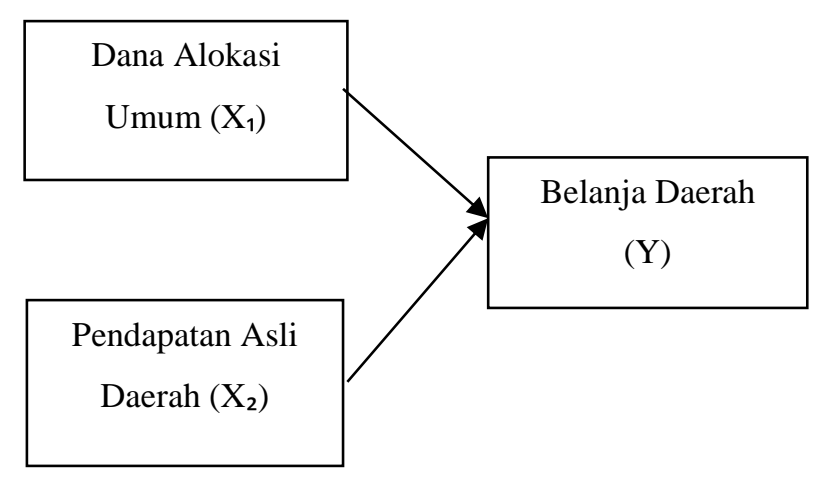

Sumber Rahmawati dan Suryono

(2015) yang dimodifikasi untuk penelitian ini.

\section{Pengembangan Hipotesis}

\section{Pengaruh Dana Alokasi Umum Terhadap Belanja Daerah.}

Teori keagenan menunjukkan bahwa dana yang berasal dari pemerintah pusat (prinsipal) dapat membantu pemerintah daerah (agen) untuk membiayai pengeluaran belanja daerahnya.

Hasil penelitian yang dilakukan Mentayani dkk (2017) menyatakan bahwa dana alokasi umum berpengaruh positif terhadap belanja daerah. berlandaskan uraian diatas maka hipotesisnya adalah sebagai berikut :

$\mathrm{H}_{1}$ : Dana Alokasi Umum Berpengaruh Positif Terhadap Belanja Daerah pada Pemerintahan/Kota Se-Eks Karesidenan Pati. 


\section{Pengaruh Pendapatan Asli Daerah Terhadap Belanja Daerah.}

Teori keagenan menjelaskan hubungan antara prinsipal dan agen. Prinsipal merancang kontrak untuk mengakomodasi kepentingan pihak agen. Pmerintah pusat (prinsipal) melimpahkan wewenang kepada pemerintah daerah (agen) untuk mengatur secara mandiri segala aktivitasnya di pemerintahanya.

Hasil penelitian yang dilakukan Rahmawati dan Suryono (2015) bahwa pendapatan asli daerah berpengaruh positif terhadap belanja daerah. Berdasarkan landasan uraian diatas maka hipotesisnya adalah sebagai berikut :

$\mathrm{H}_{2}$ : Pendapatan Asli Daerah Berpengaruh Positif Terhadap Belanja Daerah pada Pemerintahan/Kota Se-Eks Karesidenan Pati.

\section{METODE PENELITIAN}

Populasi dalam penelitian ini adalah Kabupaten/Kota Se-Eks Karesidenan Pati dari tahun 2012-2016. Data berasal dari situs resmi Dirjen Perimbangan Keuangan (www.djpk.depkeu.go.id). Penelitian ini menggunakan metode sensus yang merupakan metode dimana semua anggota populasi dijadikan sampel (Sugiyono, 2007:56) yang bersumber dari dokumen Laporan Realisasi APBD Pemerintahan/ Kota Se-Eks Karesidenan Pati .

\section{HASIL DAN PEMBAHASAN}

\section{Uji Statistik Deskriptif}

\begin{tabular}{|c|c|c|c|c|}
\hline $\begin{array}{c}\text { Variabe } \\
\text { l } \\
\text { Penelitian }\end{array}$ & Min. & Max. & Mean & $\begin{array}{c}\text { Std. } \\
\text { Deviation }\end{array}$ \\
\hline DAU & $\begin{array}{c}27,07 \\
0\end{array}$ & $\begin{array}{c}27,82 \\
0\end{array}$ & $\begin{array}{c}27,45 \\
0,180\end{array}$ \\
\hline PAD & 25,13 & 26,53 & 25,93 & 0,404 \\
& 0 & 7 & 3 & \\
& & & & \\
\hline
\end{tabular}


Sumber : hasil SPSS yang diolah, 2018.

\section{Uji Asumsi Klasik}

\section{Uji Normalitas}

Data dalam penelitian ini sebanyak 30 dengan menggunakan uji one-sample kolmogorovsmirnov test. Nilai asymp. Sig (2-tailed) lebih besar dari 0,05 yaitu 0,200 . maka data terdistribusi normal dengan demikian asumsi normalitas terpenuhi.

\section{Multikolinearitas}

Penelitian ini melakukan uji multikolinearitas dengan melihat nilai Tolerance dan Variance Inflation Factor (VIF). Model regresi yang baik adalah yang tidak terjadi multikolinearitas, ditunjukan dengan nilai tolerance $>0,10$ dan VIF $<0,10$ (Ghozali, 2016). Dimana hasil output SPSS dapat dilihat bahwa Tolerance lebih dari 0,10 dan VIF kurang dari 0,10 sehingga dapat disimpulkan bahwa tidak terjadi multikolinearitas.

Sumber : hasil SPSS yang diolah, 2018

\section{Uji Autokorelasi}

Uji autokorelasi untuk penelitian ini menggunakan uji statistik Durbin Watson Test, dengan sig -2 sampai +2 , dengan demikian dapat disimpulkan dari output spss tersebut bahwa tidak ada autokorelasi positif maupun negatif, sehingga asumsi autokorelasi terpenuhi.(Ghozali,2016).

\begin{tabular}{|c|c|c|}
\hline Persamaan & Durbin Waston & Keterangan \\
\hline Regresi & 1,594 & $\begin{array}{c}\text { Tdk ada } \\
\text { autokorelasi }\end{array}$ \\
\hline
\end{tabular}

Sumber : data SPSS yang diolah, 2018. 


\section{Uji Heteroskedastisitas}

Uji heteroskedastisitas bertujuan untuk menguji apakah dalam model regresi terjadi ketidaksamaan variance dari residual satu pengamatan ke pengamatan yang lain. Jika variance residual satu ke pengamat lain tetap, maka disebut homoskedastisitas dan jika berbeda disebut heteroskedastisitas. Model regresi yang baik adalah homoskedastisitas. Model regresi yang baik adalah yang homoskedastisitas atau tidak terjadi heteroskedastisitas (Ghozali, 2016).

Pengujian heteroskedastisitas dalam penelitian ini menggunakan uji park. Dengan asumsi apabila variabel bebas tidak berpengaruh terhadap nilai logaritma natural dari kuadrat residual (sig > 0,05) maka tidak terjadi heteroskedastisitas.

\begin{tabular}{|l|c|c|l|}
\hline Variabel & B & Sig. & \multicolumn{1}{|c|}{ Ket } \\
\hline DAU & $-0,152$ & 0,957 & $\begin{array}{l}\text { bebas } \\
\text { heteroskedastisitas }\end{array}$ \\
\hline PAD & 0,155 & 0,901 & $\begin{array}{l}\text { bebas } \\
\text { heteroskedastisitas }\end{array}$ \\
\hline
\end{tabular}

Sumber : hasil SPSS yang diolah, 2018

Analisis Regresi Berganda

\begin{tabular}{|l|c|c|c|}
\hline \multirow{2}{*}{ Variabel } & \multicolumn{2}{|c|}{$\begin{array}{l}\text { Unstandardized } \\
\text { Coefficients }\end{array}$} & $\begin{array}{c}\text { Standardiz } \\
\text { ed } \\
\text { Coefficient }\end{array}$ \\
\cline { 2 - 4 } & B & $\begin{array}{c}\text { Std. } \\
\text { Error }\end{array}$ & Beta \\
\hline (Constant) & $-0,929$ & 2,883 & \\
\hline DAU & 0,803 & 0,142 & 0,573 \\
\hline PAD & 0,268 & 0,063 & 0,428 \\
\hline
\end{tabular}

Sumber : hasil SPSS yang diolah, 2018.

Berdasarkan pada hasil perhitungan SPSS 23, maka persamaan regresi berganda adalah sebagai berikut : 
$Y=-0,929+0,803 X_{1}+0,268 X_{2}+e$

\section{Uji Koefisien Determinasi $\left(\mathbf{R}^{2}\right)$}

Hasil uji koefisiensi determinasi menunjukkan bahwa nilai Adjusted R Square diperoleh sebesar $0,87 \%$. Hal ini berarti bahwa sebesar $87 \%$ variabel belanja daerah bisa dijelaskan oleh variabel dana alokasi umum dan pendapatan asli daerah.sedangkan sisanya $13 \%$ di jelaskan oleh variabel bebas lain di luar variabel penelitian.

\section{Uji Signifikan Simultan (Uji Statistik F)}

Berdasarkan nilai signifikan sebagai $0,000<0,05$. Dengan demikian dapat disimpulkan bahwa model penelitian adalah fit atau dengan kata lain ada pengaruh yang signifikan antara dana alokasi umum, pendapatan asli daerah terhadap belanja daerah.

\section{Uji Signifikan Parameter Individual (Uji Statistik t)}

\begin{tabular}{|c|c|c|c|}
\hline Hipotesis & B & T & Sig. \\
\hline DAU & 0,803 & 5,667 & 0,000 \\
\hline PAD & 0,268 & 4,233 & 0,000 \\
\hline
\end{tabular}

Sumber : hasil SPSS yang diolah, 2018

Dalam penelitian ini dapat diketahui :

1. Berdasarkan hasil perhitungan uji statistik $\mathrm{t}$, dana alokasi umum memiliki koefisiensi 0,803 dan t hitung 5,667 dengan probabilitas (sig) 0,000. Nilai probabilitas (sig) ini kurang 0,05 sehingga dapat disimpulkan dana alokasi umum berpengaruh terhadap belanja daerah dengan arah positif. Dengan demikian hipotesis satu $\left(\mathrm{H}_{1}\right)$ diterima.

2. Berdasarkan hasil perhitungan uji statistik $t$, pendapatan asli daerah memiliki koefisiensi 0,268 dan thitung 4,233 dengan probabilitas (sig) 0,000. Nilai probabilitas (sig) ini kurang 0,05 sehingga dapat disimpulkan pendapatan asli daerah berpengaruh terhadap belanja daerah dengan arah positif. Dengan demikian hipotesis dua $\left(\mathrm{H}_{2}\right)$ diterima. 
3. Hasil penelitian menunjukkan terjadi flypaper effect di Pemerintahan/kota Se-Eks Karesidenan Pati. Ini terlihat dari nilai standartdized cefficient dana alokasi umum sebesar 0,573 yang lebih tinggi dibandingkan dengan nilai standardized coefficient pendapatan asli daerah sebesar 0,428 dimana kedua variabel sama-sama berpengaruh terhadap belanja daerah.

\section{KESIMPULAN}

Hasil dan penelitian ini menunjukkan bahwa dana alokasi umum, pendapatan asli daerah berpengaruh terhadap belanja daerah. Pmerintahan/Kota Se-Eks Karesidenan pati mengalami flypaper effect, dapat disimpulkan bahwa pemerintah daerah masih mengandalkan dana transfer dari pemerintah pusat untuk membiayai pengeluaran belanjanya sehingga otonomi daerah belum dapat tercapai.

\section{Keterbatasan}

Variabel bebas yang dimasukkan hanya mampu mempengaruhi belanja daerah sebesar 87\% sehingga masih memungkinkan adanya pengaruh variabel lainnya diluar variabel bebas dana alokasi umum dan pendapatan asli daerah.

\section{Saran}

Bagi penelitian selanjunta dapat menambah variabel-variabel lain yang dapat berpengaruh pada belanja daerah, seperti Dana Alokasi Khusus(DAK), pertumbuhan ekonomi. Apabila suatu daerah memiliki pertumbuhan ekonomi yang baik maka pemerintah daerah akan berupaya untuk menjaga pertumbuhan ekonomi tersebut dengan cara memberikan dana pembangunan yang mampu menjaga pertumbuhan ekonomi, sehingga pemerintah daerah tidak hanya memberikan dana yg lebih pada pembangunan jalan dan sarana umum yang lainya. Hal ini sesuai dengan penelitian yang dilakukan oleh wulandari dkk (2013). 


\section{DAFTAR PUSTAKA}

Abdullah dan Halim. 2006. Hubungan dan Masalah Keagenanan di Pemerintahan Daerah. Jurnal Akuntansi Pemerintahan. Vol2, Nomor 1, Hal :53-64.

Bastian dan Soepriyanto . 2003. Sistem Akuntansi Sektor Publik. Edisi Pertama. Salemba Empat. Jakarta.

Ghozali. 2016. Aplikasi Analisis Multivariete dengan program IBM SPSS 23. Edisi Delapan. Penerbit BPUD: Semarang.

Jensen, Micahel C and William H. Meckling. 1976. Theory of The Firm : Managerial Behavior, Agency Costs and Ownership Structure, The Journal of Financial Economics.

Kainde, Christian. 2013. Analisis Varians dan Pertumbuhan Belanja Daerah pada Pemerintah Kota Bitung. Jurnal EMBA. Vol. 1, No. $3: 393-400$.

Kawedar Warsito, Rohman Abdul dan Sri Handayani. 2008. Akuntansi Sektor Publik. Edisi Pertama. Percetakan Widya Karya. Semarang.

Mentayani Ida, Nurul Hayati dan Rusmanto. 2012. Flypaper Effect Dana Alokasi Umum dan Pendapatan Asli Daerah Terhadap Belanja Daerah Pada Kota dan Kabupaten di Propinsi Kalimantan Selatan. Jurnal Spread. Volume ; 2 No 1.

Rahmawati dan Suryono. 2015. Flypaper Effect Dana Alokasi Umum dan Pendapatan Asli Daerah Terhadap Belanja Daerah. Jurnal Ilmu dan Riset Akuntansi.Vol ; 4 No 9.

Sugiyono. 2012. Metodologi Penelitian Pendidikan, Pendekatan Kuantitatif, Kualitatif, dan R\&D. Bandung: Alfabeta.

Undang-Undang Republik Indonesia Nomor 22 Tahun 1999 Pemerintahan Daerah dan Perimbangan Keuangan Antara Pemerintah Pusat dan Daerah. Lembaga Negara Republik Indonesia Tahun 1999 Nomor 5. Jakarta.

Undang-Undang Republik Indonesia Nomor 25 Tahun 1999 Pemerintahan Daerah dan Perimbangan Keuangan antara Pemerintahan Pusat dan Daerah Tahun 1999. Lembaga Negara Republik Indonesia Tahun 1999 Nomor 60. Jakarta.

Undang-Undang Republik Indonesia Nomor 32 Tahun 2004 Pemerintah Daerah. 15 Oktober 2004. Lembaran Negara Republik Indonesia Tahun 2004 Nomor 125. Jakarta.

Undang-Undang Republik Indonesia Nomor 33 Tahun 2004 Perimbangan Keuangan Antara Pemerintah Pusat dan Pemerintah Daerah. 15 Oktober 2004. Lembaran Negara Republik Indonesia Tahun 2004 Nomor 165. Jakarta.

Wulandari Fitria, Asrizal dan Jolianis. 2013. Pengaruh Pertumbuhan Ekonomi (PDRB), Pendapatan Asli Daerah (PAD), dan Dana Alokasi Umum (DAU) Terhadap Belanja Daerah 


\section{P ISSN}

\section{[ACCOUNTING GLOBAL JOURNAL] E ISSN}

Di Kabupaten Pasamaran Barat. Fakuktas Pendidikan Ekonomi. Universitas Muhammadiyah Sumatera Barat 